\title{
Subjects Hospitalized With the 2009 Pandemic Influenza A (H1N1) Virus in a Respiratory Infection Unit: Clinical Factors Correlating With ICU Admission
}

\author{
Nikoletta Rovina MD PhD, Magdalini Erifaki, Paraskevi Katsaounou MD PhD, Georgia Lyxi, \\ Antonia Koutsoukou MD PhD, Nikolaos G Koulouris MD PhD, and Manos Alchanatis MD PhD
}

BACKGROUND: The 2009 pandemic influenza A (H1N1) virus was accompanied by high morbidity and mortality. The aim of this study was to describe the clinical characteristics of patients with documented 2009 influenza A (H1N1) virus admitted to a reference chest hospital, the disease outcome, and risk factors associated with ICU admission. METHODS: We assessed 109 subjects admitted to the respiratory infection unit of a hospital for chest disease with signs and symptoms of the 2009 influenza A (H1N1) virus between April 2009 and December 2010. Demographic data, comorbidities, clinical signs and symptoms, laboratory tests, radiographic findings, treatment, and final outcomes were all recorded. Factors associated with severe disease requiring ICU admission were determined. RESULTS: Ninety subjects $(82.5 \%)$ had laboratory-confirmed 2009 influenza A (H1N1). Sixty-four percent of these subjects had pneumonia on admission, 26\% had respiratory failure, and 11\% required care in the ICU. Dyspnea and the presence of infiltrates on chest x-rays were the most common signs among the subjects with H1N1. All subjects were treated with antiviral therapy, and $75 \%$ received antibiotic treatment based on their clinical and laboratory findings. The predictive factors of ICU admission were severe hypoxemia and lymphocytosis. CONCLUSIONS: The outcome of subjects with influenza A (H1N1) virus infection was influenced by the severity of the disease on admission, the subjects' underlying conditions, and complications during hospitalization. Key words: hospitalization outcome; intensive care unit; pandemic HIN1 infection. [Respir Care 2014;59(10):1560-1568. () 2014 Daedalus Enterprises]

\section{Introduction}

Following the first laboratory-confirmed 2009 influenza A (H1N1) case on May 18, 2009, Greece showed a moderate wave of transmission, followed by a stronger wave in October and a peak in incidence in November. ${ }^{1}$ The first 2009 influenza A (H1N1) cases were associated with imported transmission (eg, Greek students returning home

\footnotetext{
Drs Rovina and Koutsoukou are affiliated with the Intensive Care Unit, First Department of Respiratory Medicine, Medical School, National and Kapodistrian University of Athens and "Sotiria" Chest Diseases Hospital, Athens, Greece. Ms Erifaki, Ms Lyxi, Dr Koulouris, and Dr Alchanatis are affiliated with the First Department of Respiratory Medicine, Medical School, National and Kapodistrian University of Athens and "Sotiria" Chest Diseases Hospital, Athens, Greece. Dr Katsaounou is affiliated with the Pulmonary Department, Intensive Care Medicine, Evaggelismos Hospital, Medical School, University of Athens, Athens, Greece.
}

from abroad and foreign tourists). ${ }^{2}$ During the pandemic period, there were 18,230 reported laboratory-confirmed 2009 influenza A (H1N1) cases and 88,244 visits to emergency departments and 10,040 hospitalizations due to an influenza-like illness. Among these cases, 294 were admitted to ICUs, and 149 died from causes related to 2009 influenza A (H1N1). ${ }^{2-7}$ Since that period, influenza epidemics have resulted in an estimated 3-5 million cases of

\footnotetext{
The authors have disclosed no conflicts of interest.

Correspondence: Nikoletta Rovina MD PhD, Intensive Care Unit, First Department of Respiratory Medicine, Medical School, National and Kapodistrian University of Athens and "Sotiria" Chest Diseases Hospital, 152 Mesogeion Avenue, 11527 Athens, Greece. E-mail: nikrovina@med. uoa.gr.
}

DOI: $10.4187 /$ respcare.03049 
severe illness and 250,000-500,000 deaths each year. ${ }^{1,8,9}$ The risk of complications from influenza, including lower respiratory tract infection, hospital admissions, and death, depends on varying determinants such as age and type of comorbidity that may be present. ${ }^{8,9}$ In this context, it is of importance to characterize the risk factors predisposing for adverse outcomes. The purpose of this study was to describe the clinical characteristics of subjects with documented 2009 influenza A (H1N1) admitted to a reference chest hospital, the disease outcome, and risk factors associated with ICU admission.

\section{Methods}

This was a retrospective analysis of patients admitted to the respiratory infection unit (RIU) of the First Department of Respiratory Medicine at the Medical School of the University Athens and the "Sotiria" Chest Diseases Hospital from April 2009 to December 2010. Patients either presented to the emergency department of the hospital on their own or were referred by primary care physicians, non-reference hospitals, or other health-care facilities. The Hellenic Centre for Disease Control and Prevention prepared and provided guidelines for case and contact management and for infection control, which were sent to all reference hospitals and published on the web site (http://www.keelpno.gr; Accessed December 29, 2012).

The study sample consisted of subjects who presented to the emergency department with an influenza-like illness and were investigated for the 2009 influenza A (H1N1) virus and who were then admitted to the RIU due to underlying chronic conditions or to treat emerging complications. Influenza-like illness was defined as illness of a sudden onset with (1) fever, headache, malaise, or myalgias and (2) shortness of breath, cough, or sore throat. ${ }^{10} \mathrm{~A}$ confirmed case was defined as a positive test result for the 2009 H1N1 virus using real-time polymerase chain reaction. ${ }^{11}$ Nasopharyngeal swabs were collected and sent for analysis to a designated reference laboratory (Hellenic Pasteur Institute, Athens, Greece). All subjects admitted to the RIU were tested for the 2009 pandemic influenza A (H1N1) virus, and the results were available in $<24 \mathrm{~h}$. The study was approved by the ethics committee of the hospital.

\section{Data Collection}

Data were retrospectively collected using a standard form that included demographic characteristics, past medical history, comorbidities, prehospital medication, H1N1 vaccination, travel to endemic countries, clinical presentation, body mass index, biochemical markers, chest radiograph findings, medical treatment, and outcomes (including discharge, ICU admission, and death).

\section{QUICK LOOK}

\section{Current knowledge}

The H1N1 flu epidemic of 2009 was associated with severe hypoxemic respiratory failure in patients at risk, including those with pre-existing neuromuscular and respiratory disease, as well as obese and pregnant patients. Adjuncts to mechanical ventilation included extracorporeal membrane oxygenation, inhaled nitric oxide, and prone positioning.

\section{What this paper contributes to our knowledge}

Patients with H1N1 infection presented with greater dyspnea, tachycardia, cough, and sputum production compared with patients with flu-like symptoms but negative H1N1 swabs. Subjects with H1N1 also had more frequent infiltrates on chest radiograph, and hospital stay was twice as long. Secondary bacterial infections occurred in $76 \%$ of $\mathrm{H} 1 \mathrm{~N} 1$ subjects.

Pneumonia was defined as the presence of a new infiltrate on a chest $\mathrm{x}$-ray and fever (temperature of $\geq 38.0^{\circ} \mathrm{C}$ ) and/or respiratory symptoms. A concomitant and/or secondary bacterial co-infection was diagnosed in subjects having at least one positive blood or sputum culture and/or a positive urinary antigen. Complications were defined as any adverse incident occurring during hospitalization. Obesity was defined as a body mass index of $\geq 30$. Comorbidities were assessed by the Charlson comorbidity index. ${ }^{12}$

\section{Statistical Analysis}

Data are described as mean \pm SD and median (range). The Wilcoxon rank-sum test was used for comparison of continuous variables in 2 groups. Relationships of categorical variables were examined by the chi-square test or the Fisher exact test, when appropriate. Furthermore, a multiple stepwise logistic regression analysis was performed to examine potential independent factors related to ICU admission. The statistical significance was set at $<.05$. Statistical analysis was conducted with SPSS 17.0 (SPSS, Chicago, Illinois).

\section{Results}

During the study period, 109 subjects (all adults) were admitted to the RIU. Of these, 90 (82.5\%) proved to have positive nasopharyngeal swab results for the $2009 \mathrm{H} 1 \mathrm{~N} 1$ virus, and 19 (17.5\%) had negative swab results. The subjects with positive swab results had a mean \pm SD age of 
Table 1. Demographic Data, Symptoms, and Clinical Findings of Subjects Admitted to the Respiratory Infection Unit

\begin{tabular}{|c|c|c|c|c|}
\hline & $\begin{array}{c}\text { Total } \\
(n=109)\end{array}$ & $\begin{array}{l}\text { H1N1-Positive Subjects } \\
\quad(n=90)\end{array}$ & $\begin{array}{l}\text { H1N1-Negative Subjects } \\
(n=19)\end{array}$ & $P$ \\
\hline Age (mean $\pm \mathrm{SD})$ & $38 \pm 15$ & $37 \pm 15$ & $40 \pm 18$ & .59 \\
\hline Gender (male/female), $n$ & $45 / 64$ & $39 / 51$ & $6 / 13$ & \\
\hline Travel to an endemic country, $n(\%)$ & $41(38)$ & $38(42)$ & $3(16)$ & .01 \\
\hline Vaccination, $n$ & 1 & 0 & 0 & \\
\hline Charlson comorbidity index & $1.8 \pm 1.2$ & $1.9 \pm 1.2$ & $1.5 \pm 0.7$ & .007 \\
\hline \multicolumn{5}{|l|}{ Symptoms, $n(\%)$} \\
\hline Fever & $97(84)$ & $81(91)$ & $15(83)$ & .18 \\
\hline Tachycardia & $89(82)$ & $80(87)$ & $12(66)$ & .03 \\
\hline Dyspnea & $40(35)$ & $37(42)$ & $3(17)$ & .02 \\
\hline Expectoration & $43(37)$ & $42(47)$ & $1(5)$ & .001 \\
\hline Cough & $90(78)$ & $81(91)$ & $8(44)$ & .001 \\
\hline Sore throat & $37(32)$ & $28(32)$ & $9(50)$ & .44 \\
\hline Gastrointestinal disorders & $22(20)$ & $18(20)$ & $7(39)$ & .09 \\
\hline Confusion & $4(4)$ & $4(3)$ & 0 & .08 \\
\hline Headache & $36(33)$ & $29(33)$ & $12(67)$ & .06 \\
\hline Myalgias & $42(40)$ & $37(42)$ & $10(56)$ & .49 \\
\hline \multicolumn{5}{|l|}{ Clinical findings and outcome, $n(\%)$} \\
\hline Infiltrates on chest $x$-ray & $62(54)$ & $57(64)$ & $3(17)$ & .001 \\
\hline Respiratory failure & $26(23)$ & $23(26)$ & $3(17)$ & .11 \\
\hline Antiviral treatment & $99(86)$ & $83(92)$ & $16(83)$ & .49 \\
\hline Bacterial superinfection in sputum & $74(64)$ & $68(76)$ & $5(28)$ & .001 \\
\hline Hospitalization duration (mean $\pm \mathrm{SD}$ ), $\mathrm{d}$ & $6 \pm 3$ & $7 \pm 2$ & $3 \pm 2$ & .001 \\
\hline Admission to an ICU, $n(\%)$ & $12(11)$ & $12(13)$ & 0 & .02 \\
\hline Cure, $n(\%)$ & $108(99)$ & $89(99)$ & $19(100)$ & .11 \\
\hline Death, $n(\%)$ & $1(0.9)$ & $1(1)$ & 0 & \\
\hline
\end{tabular}

$37 \pm 15$ y compared with those with negative swab results, who had a mean age of $40 \pm 18$ y $(P>.05)$. The demographic data, symptoms, clinical manifestations, and outcomes are shown in Table 1. Twelve subjects required invasive mechanical support due to respiratory failure and were transferred to the ICU (mean \pm SD age of $52 \pm 12 \mathrm{y}$ ). The clinical and laboratory data for the subjects admitted to the ICU are shown in Figure 1. Forty-five of 109 subjects $(41 \%)$ had at least one comorbidity, with the most common conditions being asthma (19 cases, 17\%) and COPD (10 cases, 9\%). Subjects with positive swab results had significantly more comorbidities as expressed by the Charlson comorbidity index compared with those with negative swab results $(1.9 \pm 1.2$ vs $1.5 \pm 0.7, P=.007)$.

Upon hospital admission, the most common symptoms and signs were fever, tachycardia, and cough. Subjects with the 2009 H1N1 virus presented with significantly more dyspnea ( $42 \%$ vs $17 \%, P=.04)$, tachycardia $(87 \%$ vs $66 \%, P=.034)$, expectoration $(47 \%$ vs $5 \%, P=.001)$, and cough $(91 \%$ vs $44 \%, P=.001)$ compared with subjects with an influenza-like illness (see Table 1). Furthermore, $64 \%$ of subjects with the 2009 H1N1 virus had infiltrates on $\mathrm{x}$-rays at admission compared with $17 \%$ of subjects presenting with an influenza-like illness $(P=.001)$.

The mean \pm SD hospital stay was $7 \pm 2 \mathrm{~d}$ for subjects with the $2009 \mathrm{H} 1 \mathrm{~N} 1$ virus and $3 \pm 2 \mathrm{~d}$ for subjects with an influenza-like illness $(P=.001)$ (see Table 1$)$. Twelve subjects were transferred to the ICU (all with a positive swab for the 2009 H1N1 virus). Overall, only one of the H1N1 subjects died in the ICU due to shock/multiple organ failure. This subject was immunosuppressed due to human immunodeficiency virus infection.

A concomitant and/or secondary bacterial co-infection was present in $76 \%$ of subjects with the $2009 \mathrm{H} 1 \mathrm{~N} 1$ virus compared with $28 \%$ of subjects with an influenza-like illness $(P=.001)$, whereas there was a statistically significant difference in the presence of a co-infection between the subjects admitted to the RIU and ICU (Table 2). Overall, Streptococcus pneumoniae (isolated from blood and sputum and by urinary antigen testing), Haemophilus influenza (isolated from sputum and blood), Moraxella catarrhalis (isolated from sputum), and Staphylococcus aureus (isolated from sputum and blood) were the most frequent causative bacteria. Other organisms isolated were 
ICU AdMission IN the 2009 H1N1 PANDEMIC

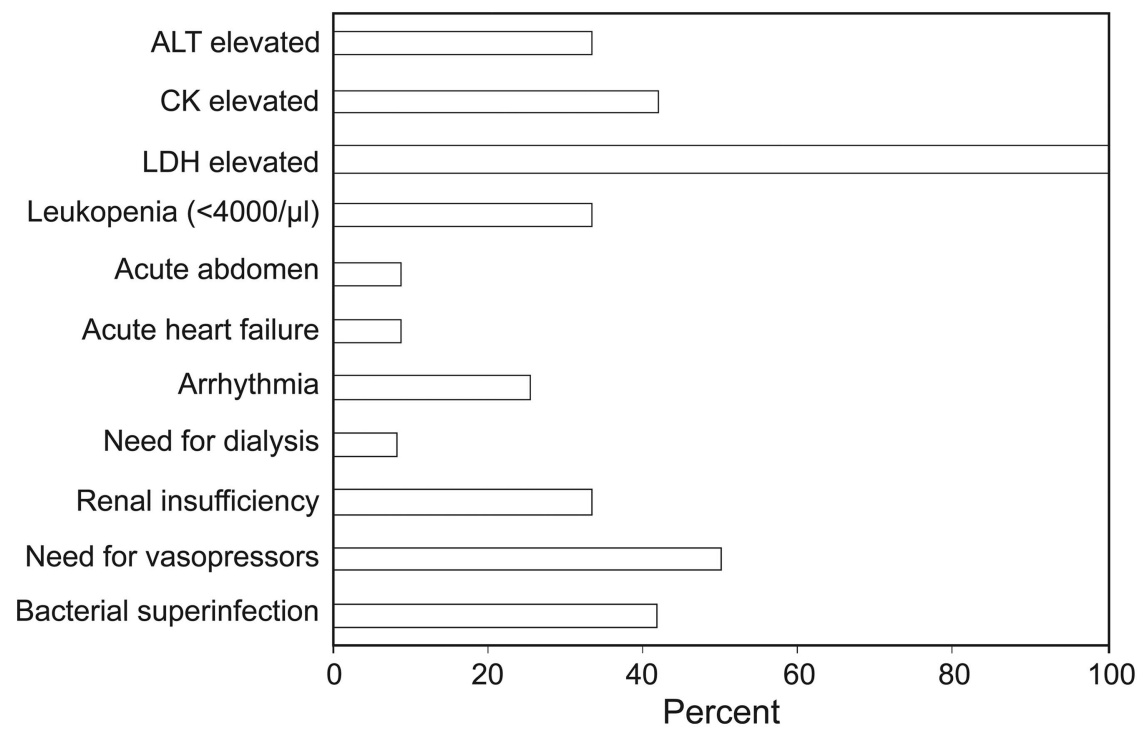

Fig. 1. Clinical and laboratory data of subjects upon admission to the ICU. ALT = alanine aminotransferase; CK $=\mathrm{creatine}$ kinase; $\mathrm{LDH}=$ lactate dehydrogenase.

Table 2. Symptoms, Clinical and Laboratory Findings, and Comorbidities for Subjects With Positive Swabs Hospitalized in the RIU and Those Hospitalized in the ICU

\begin{tabular}{|c|c|c|c|}
\hline & $\begin{array}{l}\text { Subjects in RIU } \\
\quad(n=78)\end{array}$ & $\begin{array}{l}\text { Subjects in ICU } \\
\quad(n=12)\end{array}$ & $P$ \\
\hline Age (mean $\pm S D), y$ & $38 \pm 16$ & $52 \pm 12$ & .03 \\
\hline Gender (male/female), $n$ & $39 / 51$ & $6 / 6$ & \\
\hline Travel in an endemic country, $n(\%)$ & $29(32)$ & $9(50)$ & .55 \\
\hline \multicolumn{4}{|l|}{ Symptoms, $n(\%)$} \\
\hline Fever & $87(97)$ & $10(83)$ & .37 \\
\hline Tachycardia & $77(85)$ & $12(100)$ & .09 \\
\hline Dyspnea & $33(37)$ & $7(58)$ & .36 \\
\hline Expectoration & $35(39)$ & $8(67)$ & .05 \\
\hline Gastrointestinal disorders & $23(25)$ & $2(17)$ & .52 \\
\hline Confusion & $2(2)$ & $2(17)$ & .01 \\
\hline Headache & $35(39)$ & $6(50)$ & .67 \\
\hline Myalgias & $42(47)$ & $6(50)$ & .95 \\
\hline \multicolumn{4}{|l|}{ Clinical and laboratory findings } \\
\hline Infiltrates on chest $\mathrm{x}$-ray, $n(\%)$ & $51(57)$ & $11(92)$ & .01 \\
\hline Respiratory failure on admission, $n(\%)$ & $18(19)$ & $8(67)$ & .001 \\
\hline $\mathrm{P}_{\mathrm{aO}_{2}}($ mean $\pm \mathrm{SD}), \mathrm{mm} \mathrm{Hg}$ & $70 \pm 13$ & $51 \pm 15$ & $<.001$ \\
\hline $\mathrm{S}_{\mathrm{aO}_{2}}($ mean $\pm \mathrm{SD})$ & $96.7 \pm 2$ & $89 \pm 4$ & .001 \\
\hline WBCs (mean \pm SD, absolute $n$ ) & $7,720 \pm 3,770$ & $8,260 \pm 2,319$ & .13 \\
\hline Lymphocytes (mean $\pm \mathrm{SD}$, absolute $n$ ) & $1,112 \pm 613$ & $2,065 \pm 1,350$ & .03 \\
\hline Bacterial superinfection in sputum, $n(\%)$ & $63(81)$ & $5(42)$ & .02 \\
\hline \multicolumn{4}{|l|}{ Comorbidities, $n(\%)$} \\
\hline Respiratory diseases & $28(29)$ & $6(50)$ & .03 \\
\hline Immunosuppression & $7(7)$ & $2(17)$ & .03 \\
\hline Pregnancy & $1(1)$ & 0 & \\
\hline Cardiovascular diseases & $3(3)$ & $2(17)$ & .02 \\
\hline Obesity & $2(2)$ & $1(8)$ & .07 \\
\hline \multicolumn{4}{|l|}{$\begin{array}{l}P<.05 \text { was considered to be statistically significant. } \\
\mathrm{RCU}=\text { respiratory infection unit } \\
\mathrm{S}_{\mathrm{aO}_{2}}=\text { arterial oxygen saturation } \\
\mathrm{WBCs}=\text { white blood cells }\end{array}$} \\
\hline
\end{tabular}



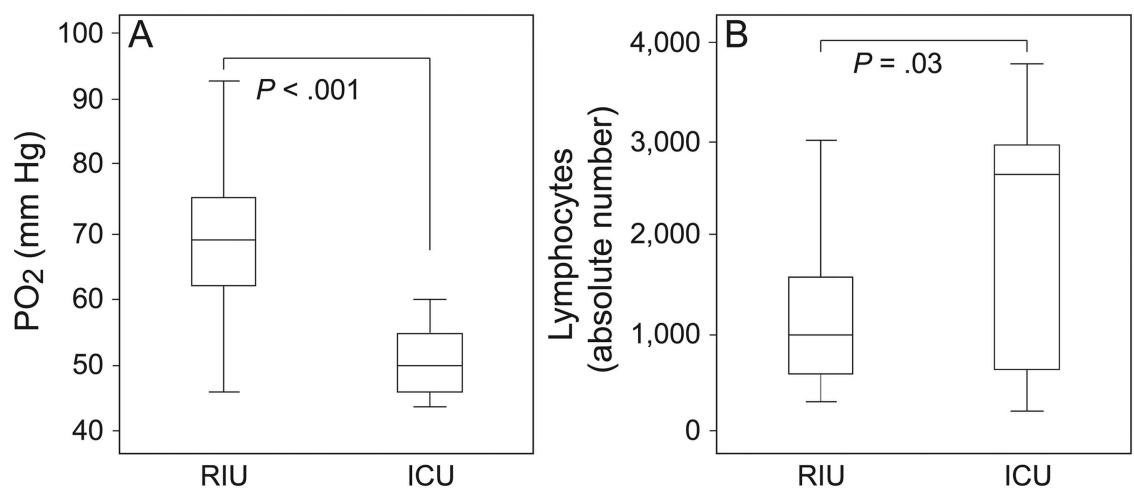

Fig. 2. Levels of $\mathrm{P}_{\mathrm{O}_{2}}$ in arterial blood gas measurement (median value, interquartile range) (A) and absolute number of lymphocytes in peripheral blood (median value, interquartile range) $(B)$ on admission of subjects to the respiratory infection unit (RIU) and ICU.

Pseudomonas aeruginosa (isolated from sputum and blood), Candida albicans, and Acinetobacter baumannii.

\section{Treatment}

Overall, 99 subjects $(91 \%)$ were treated with oseltamivir within $24 \mathrm{~h}$ of admittance at a dosage of $75 \mathrm{mg}$ twice daily, but 18 subjects who had severe respiratory failure (12 of them were in the ICU) were treated from the beginning with $150 \mathrm{mg}$ twice daily. Seventy-four subjects (68\%) received antibiotics for a median of $7 \mathrm{~d}$ (range of 1-28 d). ${ }^{13}$ No subject admitted to the ICU received steroid treatment.

\section{Factors Correlating With ICU Admission}

The demographic data, symptoms, clinical and laboratory findings, and comorbidities for the subjects treated in the RIU and ICU are shown in Table 2. With regard to symptoms, subjects who were admitted to the ICU presented to the emergency department more often with productive cough, implying an underlying bacterial superinfection, and confusion (67\% vs 39\%, $P=.04$, and $17 \%$ vs $2 \%, P=.01$, respectively).

With regard to clinical and laboratory findings, subjects who were admitted to the ICU presented to the emergency department more often with infiltrates on $\mathrm{x}$-rays (92\% vs $53 \%, P=.01)$, respiratory failure (67\% vs $19 \%, P=.001)$, lower $\mathrm{P}_{\mathrm{aO}_{2}}(51 \pm 15$ vs $70 \pm 13 \mathrm{~mm} \mathrm{Hg}, P<.001)$, and a higher absolute number of lymphocytes $(2,065 \pm 1,350$ vs $1,112 \pm 613, P=.03$ ) compared with subjects who were hospitalized in the RIU (Fig. 2, A and B; see Table $2)$. Finally, subjects in the ICU had significantly more respiratory (50\% vs $29 \%, P<.05)$, cardiovascular $(17 \%$ vs $3 \%, P<.05)$, and immunosuppressive $(17 \%$ vs $7 \%$, $P<.05)$ conditions as comorbidities compared with subjects in the RIU (see Table 2).
The presence of the 2009 influenza A (H1N1) virus significantly prolonged the hospital stay in both groups of subjects treated in the RIU or ICU (Fig. 3). Furthermore, among the subjects admitted to the ICU, those who had respiratory failure at presentation in the emergency department had a significantly higher hospital stay compared with those without respiratory failure at presentation (Fig. 4).

With the application of multiple logistic regression analysis, the prognostic factors for a subject's admission to the ICU were hypoxemia and lymphocytosis in peripheral blood (Table 3 and Fig. 5). Receiver operating characteristic analysis demonstrated that a $\mathrm{P}_{\mathrm{aO}_{2}}$ of $57.5 \mathrm{~mm} \mathrm{Hg}$ had a higher sensitivity (90\%) and specificity (83\%). The cutoff point for the number of lymphocytes in peripheral blood with the best predictive power for ICU admission was 2,400 cells/ $\mu \mathrm{L}$ (sensitivity of $59 \%$, specificity of $97.6 \%)$.

\section{Discussion}

This study summarizes the demographic characteristics of subjects who presented to the emergency department of a reference hospital with an influenza-like illness requiring hospitalization and who were investigated for the 2009 influenza A (H1N1) virus during the pandemic. Furthermore, it defines the characteristics of the subjects in this sample who required mechanical ventilation and management in the ICU.

The mean age of hospitalized subjects with the 2009 influenza A (H1N1) virus in our sample was $37 \mathrm{y}$, with $52 \mathrm{y}$ being the mean age of subjects admitted to the ICU. Our data are in accordance with previous studies showing that younger adults are more often hospitalized.14-16 This could probably be attributed to the fact that older people are partially protected by the presence of pre-existing antibodies from natural exposure to the A (H1N1) strains that circulated in the year following 1918 or to vaccine- 

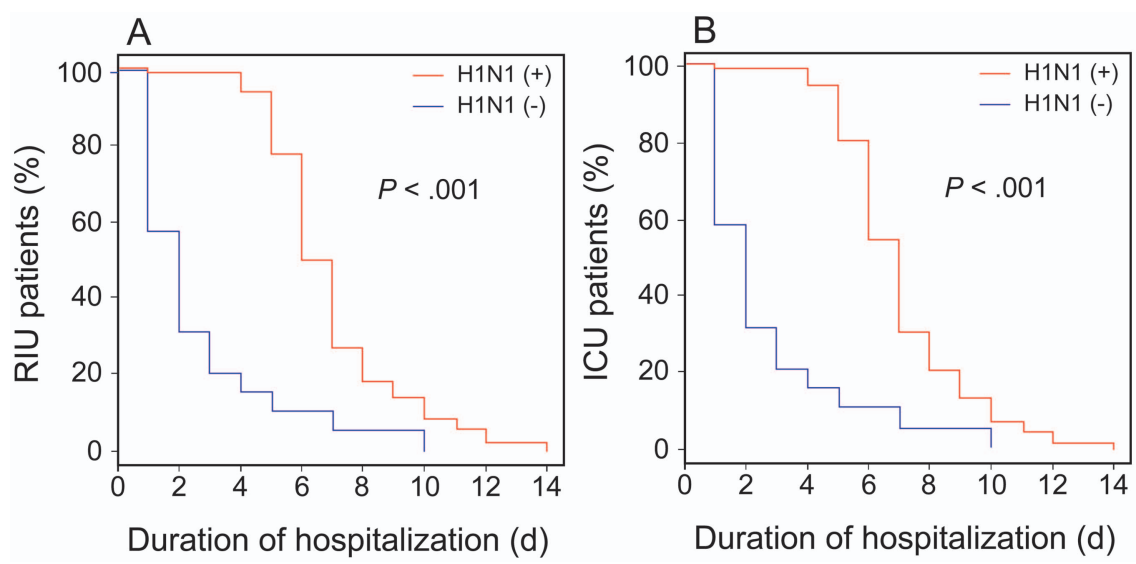

Fig. 3. The presence of the 2009 influenza A (H1N1) virus significantly prolonged the hospital stay of subjects treated in the respiratory infection unit (RIU) or ICU. H1N1 (+) = H1N1-positive; H1N1 $(-)=\mathrm{H} 1 \mathrm{~N} 1$-negative.

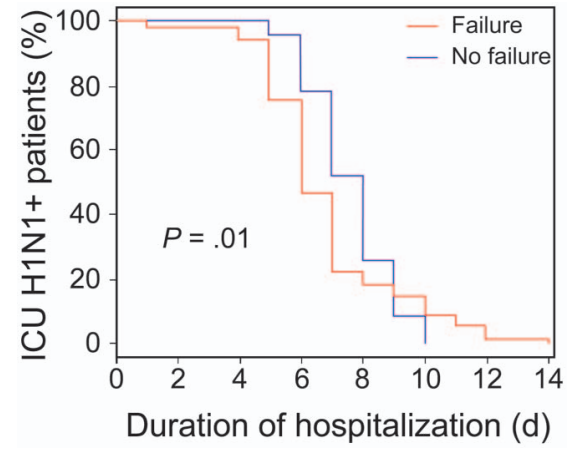

Fig. 4. Hospital stay of subjects who were positive for influenza A $(\mathrm{H} 1 \mathrm{~N} 1)$ in the ICU in relation to the presence or absence of respiratory failure on admission to the hospital.

Table 3. Prognostic Factors for ICU Admission

\begin{tabular}{lccl}
\hline \hline & $\begin{array}{c}\text { Area under } \\
\text { the curve }\end{array}$ & $95 \% \mathrm{CI}$ & \multicolumn{1}{c}{$P$} \\
\hline Hypoxemia $\left(\mathrm{P}_{\mathrm{aO}_{2}} 57.5 \mathrm{~mm} \mathrm{Hg}\right)$ & 0.89 & $0.76-1.00$ & .001 \\
Lymphocytosis $(2,400$ cells $/ \mu \mathrm{L})$ & 0.68 & $0.46-0.91$ & .04
\end{tabular}

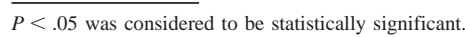

induced cross-reactivity. ${ }^{17-19}$ Although several studies have shown that current and past pandemics affected mainly younger adults, ${ }^{20,21}$ with patients younger than $50 \mathrm{y}$ having a higher risk of death, 22 in a recent meta-analysis, a significant increase in the risk of hospitalization and death was found in elderly compared with non-elderly subjects, but this risk was associated with the existence of comorbidities. ${ }^{23}$ Multivariate analyses in several studies confirmed that the presence of concomitant diseases strictly related to age and probably not independent of it might represent a greater risk factor for ICU admission and death. ${ }^{14-16}$ Forty-two percent of the subjects in our

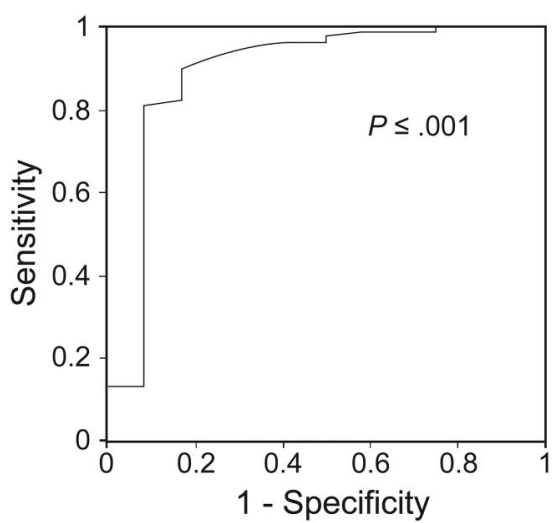

Fig. 5. Hypoxemia as a strong prognostic factor for a subject's admission to the ICU.

sample who were hospitalized had at least one comorbidity, with the most common conditions being asthma (19 cases, 17\%) and COPD (10 cases, 9\%), whereas the remaining subjects had no comorbidities. This finding is in agreement with worldwide clinical data on 2009 H1N1 virus infection, which show that $25-50 \%$ of 2009 H1N1 patients who were hospitalized or died had no underlying comorbidities. $^{24-27}$ Of the subjects admitted to the ICU, only one died. This was a subject who was positive for human immunodeficiency virus and who initially developed severe respiratory failure and finally multiple organ failure. Data show that immunosuppression increases the risk of death from pandemic influenza, and immunocompromised patients are more likely to be admitted to the hospital. ${ }^{23,28}$ In the remaining ICU subjects, the most common comorbidities were chronic respiratory diseases, namely, COPD and asthma. As shown in a recent metaanalysis, ${ }^{23}$ the presence of any chronic lung disease increased the risk of death and hospital or ICU admission, and COPD was specifically associated with ICU admission..$^{23,29,30}$ Similarly, several international studies show a 
notable incidence of asthma in subjects hospitalized with H1N1 infection. ${ }^{31-36}$ Other recognized comorbidities complicating the course of our subjects in the ICU were cardiovascular disease and immunosuppression. Cardiovascular disease is a recognized comorbidity that increases the risk of hospitalization and ICU admission ${ }^{25,37}$ and is associated with increased risk of death. ${ }^{23,37}$ Although there was a rather low percentage of subjects with the 2009 influenza A (H1N1) virus and cardiovascular disease on the ward (3\%), the relevant percentage of subjects admitted to the ICU was $17 \%$. This could be explained by the fact that the subjects treated on the ward were significantly younger than those admitted to the ICU and had less possibility of having cardiovascular health problems. The lack of evidence associating obesity, a well-defined risk factor, ${ }^{23,32}$ with hospitalization and ICU admission in our study may be due to the small size of our study groups.

In our sample, $42 \%$ of the confirmed 2009 influenza A (H1N1) cases reported travel in an endemic country. This is not an odd finding because Greece is a popular tourist destination. The first $2009 \mathrm{H} 1 \mathrm{~N} 1$ cases in Greece were associated with imported transmission (eg, students returning to Greece from abroad and foreign tourists). ${ }^{1,2}$ Subjects with an influenza-like illness presented with fever, tachycardia, and cough as the most frequent symptoms and signs on hospital admission. Subjects with the 2009 influenza A (H1N1) virus presented with significantly more dyspnea and productive cough compared with subjects with an influenza-like illness, with a documented concomitant and/or a secondary bacterial co-infection in $76 \%$ of the 2009 influenza A (H1N1) cases. Bacterial co-infections were similar to those reported in other case series. ${ }^{20,38,39}$ Although the ratio of subjects with a bacterial co-infection admitted to the RIU and ICU was relatively high, this did not affect the outcome of these subjects. This is in line with the report of Cillóniz et al, ${ }^{40}$ who showed that bacterial co-infection with H1N1 infection in subjects admitted with community-acquired pneumonia, although associated with higher severe scales on admission, did not influence the mortality. However, the significance of bacterial co-infections in the outcome of patients with influenza H1N1 should not be undermined or discarded. Several studies have shown increased morbidity and mortality in post-influenza bacterial pneumonia or coinfection. ${ }^{41,42}$ This has also been confirmed in numerous preclinical studies. ${ }^{43,44}$

Previous reports have shown that radiologically confirmed pneumonia is associated with severe outcomes. ${ }^{3,4,8,20,32}$ Although multivariate analysis did not reveal that pneumonia on admission was a significant clinical risk factor for a severe outcome in our study, it is noteworthy that $64 \%$ of subjects with 2009 H1N1 had infiltrates on x-rays at admission (92\% for ICU subjects) compared with $17 \%$ of subjects presenting with an influenza- like illness, underlining its significance in complicating the confirmed cases requiring hospitalization.

The majority of our subjects received antiviral treatment (oseltamivir) within $24 \mathrm{~h}$ of admission. Timely administration of antiviral treatment has been correlated with better outcomes and with lower prevalence of respiratory failure in patients with 2009 influenza A (H1N1) virus infection. ${ }^{45-48}$ There is a consensus that treatment should be offered to 2009 H1N1-infected individuals with a high risk of complicated influenza or with signs of lower respiratory tract involvement, and therapy should start as soon as possible after symptom onset, regardless of the clinical severity at presentation. ${ }^{46}$ Although no solid conclusions can be drawn based on this observational study, the fact that $99 \%$ of the subjects were cured suggests the importance of the timely initiation of antiviral treatment for hospitalized patients with the 2009 pandemic H1N1 virus.

Only one of the subjects in our sample had been vaccinated against the $2009 \mathrm{H} 1 \mathrm{~N} 1$ virus. Our findings are similar to those of other international studies that report an extremely low percentage of vaccinated patients. ${ }^{49,50}$ In Greece, vaccination against the 2009 H1N1 virus started at the end of November 2009, with the intention to be administered free of charge to anyone wishing to be vaccinated, aiming for global coverage. However, up to February 28, 2010, an extremely low percentage of the Greek population (3.2\%) had been vaccinated, ${ }^{51}$ whereas the relative percentage in the United States and territories for the same time period was $\sim 23.9 \% .{ }^{46}$ The main reason explaining the low vaccination percentage in Greek population was a belief that the vaccine might not be safe. ${ }^{51,52}$

Some limitations of the study should be noted. The sample size of the study was small, and this may have affected the statistical power to detect small effects. However, regardless of that, differences in the clinical presentation of subjects and outcomes were detected. In addition, factors that influenced ICU admission were observed.

In summary, in this study, the outcome of subjects with influenza A (H1N1) virus infection was influenced by the severity of the disease on admission, the subjects' underlying conditions, and complications during hospitalization.

\section{ACKNOWLEDGMENTS}

We thank Konstantinos Vougas and Christina Sotiropoulou, Athens, Greece for their valuable contribution to the statistical analysis of the study data.

\section{REFERENCES}

1. Centers for Disease Control and Prevention. People at high risk of developing flu-related complications. Updated 2012. http://www. cdc.gov/flu/about/disease/high_risk.htm. Accessed July 16, 2014.

2. Lytras T, Theocharopoulos G, Tsiodras S, Mentis A, Panagiotopoulos T, Bonovas S, Influenza Surveillance Report Group. Enhanced 
surveillance of influenza $\mathrm{A}(\mathrm{H} 1 \mathrm{~N} 1) \mathrm{v}$ in Greece during the containment phase. Euro Surveill 2009;14(29):pii 19275.

3. Panagiotopoulos T, Bonovas S, Danis K, Iliopoulos D, Dedoukou X, Pavli A, et al. Cluster of new influenza $\mathrm{A}(\mathrm{H} 1 \mathrm{~N} 1)$ cases in travellers returning from Scotland to Greece-community transmission within the European Union? Euro Surveill 2009;14(21):pii 19226.

4. Athanasiou M, Lytras T, Spala G, Triantafyllou E, Gkolfinopoulou $\mathrm{K}$, Theocharopoulos G, et al. Fatal cases associated with pandemic influenza A (H1N1) reported in Greece. PLoS Curr 2010;2:RRN1194.

5. Centers for Disease Control and Prevention (CDC). Deaths and hospitalizations related to 2009 pandemic influenza A (H1N1)-Greece, May 2009-February 2010. MMWR Morb Mortal Wkly Rep 2010; 59(22):682-686.

6. Sypsa V, Bonovas S, Tsiodras S, Baka A, Efstathiou P, Malliori M, et al. Estimating the disease burden of 2009 pandemic influenza A(H1N1) from surveillance and household surveys in Greece. PLoS ONE 2011;6(6):e20593.

7. Nikolopoulos G, Bagos P, Lytras T, Bonovas S. An ecological study of the determinants of differences in 2009 pandemic influenza mortality rates between countries in Europe. PLoS ONE 2011;6(5): e19432.

8. World Health Organization. Influenza (seasonal) Fact sheet No. 211. Updated 2014. www.who.int/mediacentre/factsheets/fs211/en/ index.html. Accessed July 16, 2014.

9. World Health Organization. Global alert and response (GAR). WHO recommendations for the post-pandemic period. Pandemic (H1N1) 2009 briefing note 23,2010 . http://www.who.int/csr/disease/swineflu/notes/briefing_20100810/en/index.html. Accessed July 16, 2014.

10. Centers for Disease Control and Prevention. Interim guidance on case definitions to be used for investigations of novel influenza $\mathrm{A}$ (H1N1)v virus cases. http://www.cdc.gov/h1n1flu/casedef.htm. Accessed July 16, 2014.

11. Ward CL, Dempsey MH, Ring CJ, Kempson RE, Zhang L, Gor D, et al. Design and performance testing of quantitative real time PCR assays for influenza A and B viral load measurement. J Clin Virol 2004;29(3):179-188.

12. Charlson ME, Pompei P, Ales KL, MacKenzie CR. A new method of classifying prognostic comorbidity in longitudinal studies: development and validation. J Chronic Dis 1987;40(5):373-383.

13. Smith JR, Rayner CR, Donner B, Wollenhaupt M, Klumpp K, Dutkowski R. Oseltamivir in seasonal, pandemic, and avian influenza: a comprehensive review of 10-years clinical experience. Adv Ther 2011;28(11):927-959.

14. Van Kerkhove MD, Vandemaele KA, Shinde V, Jaramillo-Gutierrez G, Koukounari A, Donnelly CA, et al. Risk factors for severe outcomes following 2009 influenza A (H1N1) infection: a global pooled analysis. PLoS Med 2011;8(7):e1001053.

15. Cardeñosa N, Rodés A, Follia N, Plasencia E, Lafuente S, Arias C, et al. Epidemiological analysis of severe hospitalized 2009 pandemic influenza A (H1N1) cases in Catalonia, Spain. Hum Vaccin 2011; 7(Suppl):226-229.

16. Fuhrman C, Bonmarin I, Paty AC, Duport N, Chiron E, Lucas E, et al. Severe hospitalised 2009 pandemic influenza A(H1N1) cases in France, 1 July-15 November 2009. Euro Surveill 2010;15(2); pii 19463.

17. Hancock K, Veguilla V, Lu X, Zhong W, Butler EN, Sun H, et al. Cross-reactive antibody responses to the 2009 pandemic H1N1 influenza virus. N Engl J Med 2009;361(20):1945-1952.

18. Lee VJ, Tay JK, Chen MI, Phoon MC, Xie ML, Wu Y, et al. Inactivated trivalent seasonal influenza vaccine induces limited crossreactive neutralizing antibody responses against 2009 pandemic and 1934 PR8 H1N1 strains. Vaccine 2010;28(42):6852-6857.

19. Iorio AM, Camilloni B, Lepri E, Neri M, Basileo M, Azzi A. Induction of cross-reactive antibodies to 2009 pandemic H1N1 influ- enza virus (pH1N1) after seasonal vaccination (Winter 2003/04 and 2007/08). Proc Vaccinol 2011;4:50-58.

20. Gill JR, Sheng ZM, Ely SF, Guinee DG, Beasley MB, Suh J, et al. Pulmonary pathologic findings of fatal 2009 pandemic influenza A/ H1N1 viral infections. Arch Pathol Lab Med 2010;134(2):235-243.

21. Writing Committee of the Second World Health Organization Consultation on Clinical Aspects of Human Infection with Avian Influenza A (H5N1) Virus, Abdel-Ghafar AN, Chotpitayasunondh T, Gao Z, Hayden FG, Nguyen DH, et al. Update on avian influenza A (H5N1) virus infection in humans. N Engl J Med 2008;358(3): 261-273.

22. Echevarría-Zuno S, Mejía-Aranguré JM, Mar-Obeso AJ, GrajalesMuñiz C, Robles-Pérez E, González-León M, et al. Infection and death from influenza A H1N1 virus in Mexico: a retrospective analysis. Lancet 2009;374(9707):2072-2079.

23. Mertz D, Kim TH, Johnstone J, Lam PP, Science M, Kuster SP, et al. Populations at risk for severe or complicated influenza illness: systematic review and meta-analysis. BMJ 2013;347:f5061.

24. Donaldson LJ, Rutter PD, Ellis BM, Greaves FE, Mytton OT, Pebody RG, Yardley IE. Mortality from pandemic A/H1N1 2009 influenza in England: public health surveillance study. BMJ 2009; 339:b5213.

25. Louie JK, Acosta M, Winter K, Jean C, Gavali S, Schechter R, et al. Factors associated with death or hospitalization due to pandemic 2009 influenza $\mathrm{A}(\mathrm{H} 1 \mathrm{~N} 1)$ infection in California. JAMA 2009; 302(17):1896-902.

26. Kumar A, Zarychanski R, Pinto R, Cook DJ, Marshall J, Lacroix J, et al. Critically ill patients with 2009 influenza A (H1N1) infection in Canada. JAMA 2009;302(17):1872-1879.

27. ANZIC Influenza Investigators, Webb SA, Pettilä V, Seppelt I, Bellomo R, Bailey M, et al. Critical care services and 2009 H1N1 influenza in Australia and New Zealand. N Engl J Med 2009;361(20): 1925-1934.

28. Cordero E, Aydillo T, Fariñas MC, Paño-Pardo JR, Pachón J, Viasus D, et al. Immunosupressed patients with pandemic influenza A 2009 (H1N1) virus infection. Eur J Clin Microbiol Infect Dis 2012;31(4): 547-556.

29. McKenna JJ, Bramley AM, Skarbinski J, Fry AM, Finelli L, Jain S, et al. Asthma in patients hospitalized with pandemic influenza A(H1N1)pdm09 virus infection-United States, 2009. BMC Infect Dis 2013;13:57.

30. de Miguel-Diez J, Carrasco-Garrido P, Hernández-Barrera V, Rodríguez-Rodríguez P, Puente-Maestu L, de Miguel AG, et al. Hospitalizations from pandemic influenza ( $\mathrm{pH} 1 \mathrm{~N} 1)$ infections among patients with asthma or COPD in Spain. J Infect 2012;65(1):95-98.

31. Akinbami LJ, Moorman JE, Liu X. Asthma prevalence, health care use, and mortality: United States 2005-2009. Natl Health Stat Rep 2011;32:1-14. http://www.cdc.gov/nchs/data/nhsr/nhsr032.pdf. Accessed July 16, 2014.

32. Nguyen-Van-Tam JS, Openshaw PJ, Hashim A, Gadd EM, Lim WS, Semple MG, et al. Risk factors for hospitalization and poor outcome with pandemic A/H1N1 influenza: United Kingdom first wave (MaySeptember 2009).Thorax 2010;65(7):645-651.

33. Cullen G, Martin J, O'Donnell J, Boland M, Canny M, Keane E, et al. Surveillance of the first 205 confirmed hospitalised cases of pandemic H1N1 influenza in Ireland, 28 April-3 October 2009. Euro Surveill 2009;14(44):pii 19389.

34. Denholm JT, Gordon CL, Johnson PD, Hewagama SS, Stuart RL, Aboltins C, et al. Hospitalised adult patients with pandemic (H1N1) 2009 influenza in Melbourne, Australia. MJA 2010;192(2):84-86.

35. Santa-Olalla Peralta P, Cortes-García M, Vicente-Herrero M, Castrillo-Villamandos C, Arias-Bohigas P, Pachon-del Amo I, et al. Risk factors for disease severity among hospitalised patients with 
2009 pandemic influenza A (H1N1) in Spain, April-December 2009. Euro Surveill 2010;15(38):pii 19667.

36. Subramony H, Lai FY, Ang LW, Cutter JL, Lim PL, James L. An epidemiological study of 1348 cases of pandemic H1N1 influenza admitted to Singapore hospitals from July to Septembeer 2009. Ann Acad Med Singapore 2010;39(4):283-288.

37. Martin SS, Hollingsworth CL, Norfolk SG, Wolfe CR, Hollingsworth JW. Reversible cardiac dysfunction associated with pandemic 2009 influenza A(H1N1). Chest 2010;137(5):1195-1197.

38. Kok J, Blyth CC, Foo H, Bailey MJ, Pilcher DV, Webb SA, et al. Viral pneumonitis is increased in obese patients during the first wave of pandemic A(H1N1) 2009 virus. PLoS ONE 2013;8(2):e55631.

39. Gutiérrez-Cuadra M, González-Fernández JL, Rodríguez-Cundin P, Fariñas-Álvarez C, San Juan MV, Parra JA, et al. Clinical characteristics and outcome of patients with pandemic 2009 influenza $\mathrm{A}(\mathrm{H} 1 \mathrm{~N} 1) \mathrm{v}$ virus infection admitted to hospitals with different levels of health-care. Rev Esp Quimioter 2012;25(1):56-64.

40. Cillóniz C, Ewig S, Menéndez R, Ferrer M, Polverino E, Reyes S, et al. Bacterial co-infection with H1N1 infection in patients admitted with community acquired pneumonia. J Infect 2012;65(3):223-230.

41. Morens DM, Taubenberger JK, Fauci AS. Predominant role of bacterial pneumonia as a cause of death in pandemic influenza: implications for pandemic influenza preparedness. J Infect Dis 2008; 198(7):962-970

42. Champunot R, Tanjatham S, Kerdsin A, Puangpatra P, Wangsai S, Treebuphachatsakul P, et al. Impact of pandemic influenza (H1N1) virus-associated community-acquired pneumonia among adults in a tertiary hospital in Thailand. Jpn J Infect Dis 2010;63(4):251-256.

43. Wong SM, Bernui M, Shen H, Akerley BJ. Genome-wide fitness profiling reveals adaptations required by Haemophilus in coinfection with influenza A virus in the murine lung. Proc Natl Acad Sci USA 2013;110(38):15413-15418.

44. Jamieson AM, Pasman L, Yu S, Gamradt P, Homer RJ, Decker T, Medzhitov R. Role of tissue protection in lethal respiratory viralbacterial coinfection. Science 2013;340(6137):1230-1234.
45. Viasus D, Paño-Pardo JR, Pachón J, Riera M, López-Medrano F, Payeras A, et al. Timing of oseltamivir administration and outcomes in hospitalized adults with pandemic 2009 influenza A (H1N1) virus infection. Chest 2011;140(4):1025-1032.

46. Fiore AE, Fry A, Shay D, Gubareva L, Bresee JS, Uyeki TM, Centers for Disease Control and Prevention (CDC). Antiviral agents for the treatment and chemoprophylaxis of influenza-recommendations of the Advisory Committee on Immunization Practices (ACIP). MMWR Recomm Rep 2011;60(1):1-24.

47. Rodríguez A, Díaz E, Martín-Loeches I, Sandiumenge A, Canadell L, Díaz JJ, et al. Impact of early oseltamivir treatment on outcome in critically ill patients with 2009 pandemic influenza A. J Antimicrob Chemother 2011;66(5):1140-1149.

48. Kawai N, Ikematsu H, Tanaka O, Matsuura S, Maeda T, Yamauchi $\mathrm{S}$, et al. Comparison of the clinical symptoms and the effectiveness of neuraminidase inhibitors for patients with pandemic influenza H1N1 2009 or seasonal H1N1 influenza in the 2007-2008 and 20082009 seasons. J Infect Chemother 2011;17(3):375-381.

49. Trivellin V, Gandini V, Nespoli L. Low adherence to influenza vaccination campaigns: is the H1N1 virus pandemic to be blamed? Ital J Pediatr 2011;10:37:54.

50. Centers for Disease Control and Prevention. Interim results: statespecific Influenza A (H1N1) 2009 monovalent vaccination coverageUnited States, October 2009-January 2010. MMWR Morb Mortal Wkly Rep 2010;59(12):363-368.

51. Tsiodras S, Sypsa V, Hatzakis A. The vaccination campaign against 2009 pandemic influenza A (H1N1) and its continued importance in view of the uncertainty surrounding the risk associated with the pandemic. Euro Surveill 2010;15(3):pii 19468.

52. Sypsa V, Livanios T, Psichogiou M, Malliori M, Tsiodras S, Nikolakopoulos I, Hatzakis A. Public perceptions in relation to intention to receive pandemic influenza vaccination in a random population sample: evidence from a cross-sectional telephone survey. Euro Surveill 2009;14(49):pii 19437. 